This is an electronic reprint of the original article. This reprint may differ from the original in pagination and typographic detail.

Author(s): Pakkanen, Hannu; Alén, Raimo

Title: $\quad$ Alkali consumption of aliphatic carboxylic acids during alkaline pulping of wood and nonwood feedstocks

Year: $\quad 2013$

Version:

Please cite the original version:

Pakkanen, H., \& Alén, R. (2013). Alkali consumption of aliphatic carboxylic acids during alkaline pulping of wood and nonwood feedstocks. Holzforschung:

international journal of the biology, chemistry, physics and technology of wood, 67(6), 643-650. https://doi.org/10.1515/hf-2012-0143

All material supplied via JYX is protected by copyright and other intellectual property rights, and duplication or sale of all or part of any of the repository collections is not permitted, except that material may be duplicated by you for your research use or educational purposes in electronic or print form. You must obtain permission for any other use. Electronic or print copies may not be offered, whether for sale or otherwise to anyone who is not an authorised user. 


\section{Alkali consumption of aliphatic carboxylic acids during alkaline pulping of wood and nonwood feedstocks}

\begin{abstract}
The carbohydrate degradation products have been examined, which are formed during the conventional kraft pulping of a softwood, hardwoods, bamboo, and wheat straw as well as soda and soda-anthraquinone pulping of wheat straw. The focus was on "volatile" acids such as formic and acetic acids and "nonvolatile" hydroxy monocarboxylic and dicarboxylic acids. The different consumption profiles were obtained for the charged alkali required for the neutralization of these aliphatic acids depending on the feedstock and the cooking method. The relative composition of the acid fraction in the black liquors of softwood and hardwood and nonwood feedstocks showed characteristic variations. However, in the case of wood kraft pulping, the variations in cooking conditions (effective alkali $19-21 \%$ and cooking temperature 155$170^{\circ} \mathrm{C}$ ) had no significant effect on the acid composition. The total amount of volatile and hydroxy acids formed during pulping at a typical target $\kappa$ number level for each feedstock ranged from 78 to $174 \mathrm{~kg} \mathrm{ton}^{-1}$ based on o.d. feedstock. It was highest in birch kraft pulping and lowest in wheat soda-anthraquinone pulping.
\end{abstract}

Keywords: aliphatic carboxylic acids, alkaline pulping, bamboo, black liquor, deacetylation, hardwood, softwood, wheat straw

*Corresponding author: Hannu Pakkanen, Laboratory of Applied Chemistry, Department of Chemistry, University of Jyväskylä, P.O. Box 35, Fl-40014 Jyväskylä, Finland, e-mail: hannu.pakkanen@jyu.fi Raimo Alén: Laboratory of Applied Chemistry, Department of Chemistry, University of Jyväskylä, Finland

\section{Introduction}

During alkaline delignification, such as in kraft and sodaanthraquinone (AQ) pulping, roughly half of the initial wood material is degraded and dissolved in the cooking liquor ["black liquor” (BL)] (Sjöström 1993; Alén 2000). The multiple reactions of lignin and polysaccharides are quite complex and still not completely understood. A substantial amount of aliphatic carboxylic acids ("volatile" formic and acetic acids as well as the "nonvolatile" hydroxy monocarboxylic and dicarboxylic acids) is formed due to the low selectivity of alkaline pulping. These carbohydrate-based degradation products are also present in the $\mathrm{BL}$ along with the degradation products of lignin. The composition and total amount of the acid fraction mainly depends on the raw material and the pulping conditions. It is well accepted for kraft pulping that hydrogen sulfide ions (HS) primarily react with lignin and that carbohydrate reactions are only affected by the alkalinity (i.e., HO- ion concentration) (Alén 2000).

Wood carbohydrates are attacked at comparatively low temperatures, when the chips come into contact with the cooking liquor (Fengel and Wegener 1989; Sjöström 1993; Alén 2000). In the course of carbohydrate losses, also called "yield loss," $50-60 \%$ and $10-15 \%$ of the initial hemicelluloses and cellulose, respectively, are degraded. The most important alkali-catalyzed reactions responsible for this yield loss include the dissolution of undegraded and degraded carbohydrate chains, the deacetylation of acetyl groups in hemicellulose chains, the peeling of different monosaccharide end-units in carbohydrate chains (the "peeling reaction" or "primary peeling"), and the random alkaline hydrolysis of glycosidic bonds in carbohydrate chains followed by a subsequent peeling reaction ("secondary peeling") (Alén 2000). In conventional cooking, the cleavage of glycosidic bonds is of importance only at higher temperatures, that is, above $150^{\circ} \mathrm{C}$ for hemicelluloses (Fengel and Wegener 1989) and above $170^{\circ} \mathrm{C}$ for cellulose (Nevell 1985).

The peeling reaction results in the formation of a large number of aliphatic carboxylic acids. Of the most abundant hydroxy acids, 3,4-dideoxy-pentonic and glucoisosaccharinic acids are formed from glucomannan and cellulose (hexosans), whereas 2-hydroxybutanoic and xyloisosaccharinic acids are formed from xylan (pentosan) (Alén 2011). In contrast, the prominent glycolic, lactic, and 3-deoxy-pentonic acids, as well as the volatile formic acid, are obtained from all the polysaccharide constituents of wood. The detailed information on the origin and the composition of polysaccharide degradation products in 
BLs are well documented in the literature (Malinen and Sjöström 1975; Löwendahl et al. 1976a; Niemelä et al. 1985; Niemelä 1988, 1989, 1990; Alén et al. 1985b; Niemelä and Alén 1999; Knill and Kennedy 2003; Rautiainen and Alén 2010). The possible formation routes of degradation products were presented based on model compound studies (Alfredsson and Samuelson 1968; Löwendahl et al. 1976b; Johansson and Samuelson 1977; Sjöström 1977).

The present article is aiming at the revisiting of the behavior of the main chemical constituents of lignocellulosic materials from wood and nonwood feedstocks during alkaline pulping. The formation of aliphatic carboxylic acids with low molecular mass should also be observed as a result of conventional alkaline delignification. The consumption profile of charged alkali should also be put in relation to the formation and reactions of these acids. In focus are one softwood (SW; a mixture of pine/spruce), two hardwoods (HWs; birch and aspen), and two nonwood feedstocks (bamboo and wheat straw), which were primarily delignified by kraft pulping. In each case, the soluble acids present in BLs were analyzed by means of gas chromatography (GC) during delignification. The expectation was that the synoptic presentation of the data collected from many lignocellulosic feedstock could elevate the transparency and complete the existing data material. An improved knowledge with this regard could be useful in the future studies for developing models for alkaline pulping and concepts for recovering aliphatic carboxylic acids from BLs.

\section{Materials and methods}

\section{Cooking experiments}

The conventional laboratory-scale kraft pulping experiments were conducted in 1.251 rotating stainless steel autoclaves heated in a decene bath (CRS Autoclave System 420). A SW chip mixture $[75 \%$ Scots pine (Pinus sylvestris) and 25\% Norway spruce (Picea abies)], silver/white birch (Betula pendula/B. pubescens), aspen (Populus tremula), and bamboo (Bambusa procera) were delignified by kraft pulping and cultivated wheat (Triticum aestivum) straw by kraft and soda/soda-AQ pulping. The bamboo originated from central Vietnam and all the other raw materials were of Finnish origin.

The wood chips for pulping were laboratory screened (SCAN-CM 40:01) and the chips with knots and bark residues were eliminated. Bamboo and wheat straw were cut to a length distribution of $3-5 \mathrm{~cm}$, and both knots and leaves were removed. The chemical content of the raw materials is presented in Table 1. The cooking parameters employed in these cooking series [effective alkali (EA), sulfidity, liquor-to-feedstock ratio, cooking temperature, and $\mathrm{H}$-factor range] and some data on the pulps ( $\kappa$ number and total yield range) are presented in Table 2. In all cooks, the initial temperature was $80^{\circ} \mathrm{C}$ and the heating-up rate to the maximum cooking temperature was $1^{\circ} \mathrm{C}$ $\mathrm{min}^{-1}$. The amount of $\mathrm{AQ}$ added to the wheat straw soda-AQ pulping
Table 1 Chemical composition of the feedstocks used for cooking experiments.

\begin{tabular}{lrrrrrr}
\hline Component & SW & \multicolumn{3}{r}{ HWs } & & \multicolumn{2}{r}{ Nonwoods } \\
\cline { 3 - 4 } \cline { 6 - 7 } \cline { 6 - 7 } & & Aspen & Birch & & Bamboo & Wheat \\
\hline Carbohydrates (\%) $^{\text {a }}$ & 60.4 & 65.1 & 62.9 & & 62.7 & 55.9 \\
Arabinose (\%) & 1.5 & 0.6 & 0.5 & & 0.9 & 1.7 \\
Galactose (\%) & 1.9 & 0.8 & 1.1 & & 0.6 & 0.5 \\
Glucose (\%) & 40.8 & 44.1 & 41.5 & & 45.2 & 37.7 \\
Mannose (\%) & 11.4 & 2.2 & 1.1 & & 0.3 & 0.2 \\
Xylose (\%) & 4.8 & 17.4 & 18.7 & & 15.7 & 15.8 \\
Lignin (\%) & 27.0 & 21.7 & 24.1 & & 25.8 & 24.3 \\
Klason (\%) & 26.5 & 18.8 & 21.0 & & 24.5 & 21.2 \\
Acid-soluble (\%) & 0.5 & 2.9 & 3.1 & & 1.3 & 3.1 \\
Extractives (\%) & 2.2 & 3.0 & 2.6 & & 0.8 & 1.3 \\
Others (\%) & 10.4 & 10.2 & 10.4 & & 10.7 & 18.5 \\
Total (\%) & 100.0 & 100.0 & 100.0 & & 100.0 & 100.0 \\
\hline
\end{tabular}

a Monosaccharides as anhydro sugars. ${ }^{b}$ Containing acetyl and uronic acid groups of xylan, some pectins and other polysaccharides, proteins, and inorganics.

was $0.05 \%$ based on the o.d. feedstock. The $\kappa$ number of the pulp was determined according to the standard test method SCAN-C 1:00.

\section{Analysis of feedstock materials}

For the chemical analyses, air-dried wood and pulp samples were first ground in a Retsch SM 100 cutting laboratory mill (Retsch $\mathrm{GmbH}$, Haan, Germany) equipped with a bottom sieve with trapezoid holes (with a perforation size of $<1.0 \mathrm{~mm}$ ). Before the analyses, all samples were stored in a freezer at $-18^{\circ} \mathrm{C}$, and their moisture content was determined gravimetrically after keeping the samples in an oven at $105^{\circ} \mathrm{C}$ for $24 \mathrm{~h}$.

The grounded samples were submitted to extraction with acetone according to TAPPI T $280 \mathrm{pm}-99$ ( $4 \mathrm{~h}$ extraction time in a Soxhlet apparatus). The acid hydrolysis of the extractive free feedstock and pulp samples was done according to TAPPI T $249 \mathrm{~cm}-00$ and the resulting monosaccharides were determined by a Dionex highperformance anion exchange chromatograph equipped with pulsed amperometric detection (HPAEC/PAD). A gradient elution (Table 3) was performed at a flow rate of $0.3 \mathrm{ml} \mathrm{min}{ }^{-1}$ with the eluents: (A) ultrahigh-quality water (internal resistance $\geq 18.2 \mathrm{M} \Omega \mathrm{cm}$; Milli-Q Plus; Millipore, Bedford, MA) and (B) $100 \mathrm{mM} \mathrm{NaOH}$ with an addition of (C) $100 \mathrm{mM} \mathrm{NaOH}+500 \mathrm{mM} \mathrm{CH}_{3} \mathrm{COONa}$ for cleaning. Columns: CarboPac PA1 ( $250 \times 2$ mm i.d.; Dionex, Sunnyvale, CA) analytical column and the corresponding guard column CarboPac PA-1 G $(50 \times 2 \mathrm{~mm}$ i.d.). The flow rate of the post-column eluent (300 $\mathrm{mM} \mathrm{NaOH}$ ) was $0.1 \mathrm{ml} \mathrm{min}^{-1}$. Detection: Dionex ED-50 pulsed amperometric detector (Dionex) equipped with a disposable working electrode by using a waveform A for carbohydrates (Dionex Technical Note 21). L-fucose (SigmaAldrich, St. Louis, MO) was the internal standard and D-arabinose, D-galactose, D-glucose, D-mannose, and D-xylose (Fluka Chemical, Germany) were the sugar standards. The results from the HPAEC/PAD analysis were converted to polysaccharides (i.e., to monosaccharide anhydro forms) by multiplying the results of monosaccharides obtained, with factors 0.88 for pentoses and 0.90 for hexoses. 
Table 2 Cooking data of the feedstocks.

\begin{tabular}{|c|c|c|c|c|c|c|c|c|c|c|}
\hline \multirow[t]{2}{*}{ Parameters } & \multirow{2}{*}{$\frac{\text { SW }}{\text { Kraft }}$} & \multirow[b]{2}{*}{ Kraft } & \multirow{2}{*}{$\frac{\text { Birch }}{\text { Kraft }}$} & \multicolumn{2}{|r|}{ Aspen } & \multicolumn{2}{|c|}{ Bamboo } & \multicolumn{3}{|c|}{ Wheat straw } \\
\hline & & & & Kraft & Kraft & Kraft & Kraft & Kraft & Soda-AQ & Soda \\
\hline$E A^{a}(\%)$ & 19 & 19 & 21 & 19 & 20 & 16 & 20 & 15 & 15 & 18 \\
\hline $\mathrm{EA}^{\mathrm{b}}\left(\mathrm{mol} \mathrm{l} \mathrm{l}^{-1}\right)$ & 1.05 & 1.05 & 1.17 & 1.05 & 1.11 & 1.0 & 1.25 & 0.75 & 0.75 & 0.9 \\
\hline Sulfidity (\%) & 35 & 35 & 35 & 35 & 35 & 25 & 25 & 30 & 0 & 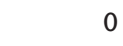 \\
\hline Liquor-to-solid ratio $\left(\mathrm{kg}^{-1}\right)$ & 4.5 & 4.5 & 4.5 & 4.5 & 4.5 & 4 & 4 & 5 & 5 & 5 \\
\hline Maximum cooking temperature $\left({ }^{\circ} \mathrm{C}\right)$ & 170 & 162 & 165 & 155 & 160 & 165 & 165 & 145 & 145 & 165 \\
\hline $\mathrm{H}$-factor ${ }^{\mathrm{c}}$ to $\mathrm{T}_{\max }$ & 179 & 89 & 116 & 47 & 74 & 116 & 116 & 18 & 18 & 116 \\
\hline $\mathrm{H}$-factor range & $7 \rightarrow 2500$ & $4 \rightarrow 1030$ & $2 \rightarrow 1640$ & $2 \rightarrow 697$ & $4 \rightarrow 1010$ & 623 & 1080 & $1 \rightarrow 97$ & $1 \rightarrow 97$ & $80 \rightarrow 380$ \\
\hline Final $\kappa$ number & 20 & 18 & 16 & 20 & 15 & 23 & 13 & 12 & 14 & 14 \\
\hline Total yield range (\%) & $78 \rightarrow 43$ & $82 \rightarrow 51$ & $82 \rightarrow 49$ & $78 \rightarrow 53$ & $77 \rightarrow 52$ & 51.9 & 48.7 & $56 \rightarrow 45$ & $56 \rightarrow 47$ & $48 \rightarrow 44$ \\
\hline
\end{tabular}

${ }^{a} \mathrm{EA}$ on o.d. feedstock (\% as $\mathrm{NaOH}$ ). ${ }^{\mathrm{b}} \mathrm{EA}$ concentration in the white liquor (calculated as $\mathrm{NaOH}$ ). ${ }^{\mathrm{c}} \mathrm{H}$-factor during heating up to $\mathrm{T}_{\max }$. In all cases, the initial temperature was $80^{\circ} \mathrm{C}$ and the heating-up rate $1^{\circ} \mathrm{C} \mathrm{min}^{-1}$.

Table 3 Gradient program used in the HPAEC/PAD analysis of monosaccharides with (A) ultra-high-quality water and (B) $100 \mathrm{mM}$ $\mathrm{NaOH}$, with an addition of (C) $100 \mathrm{mM} \mathrm{NaOH}+500 \mathrm{mM} \mathrm{CH}_{3} \mathrm{COONa}$ for cleaning.

\begin{tabular}{rrrr}
\hline Time (min) & A (\%) & B (\%) & C (\%) \\
\hline-10 & 100 & 0 & 0 \\
0 & 100 & 0 & 0 \\
2 & 100 & 0 & 0 \\
2.2 & 98 & 2 & 0 \\
26 & 98 & 2 & 0 \\
39 & 50 & 50 & 0 \\
41 & 0 & 0 & 100 \\
47 & 0 & 0 & 100 \\
\hline
\end{tabular}

The lignin content of the wood and pulp samples was calculated as a sum of the "acid-insoluble Klason lignin" (TAPPI T 222 om-98 and TAPPI T $249 \mathrm{~cm}-00$ ) and the "acid-soluble lignin". Sample powder was first treated with sulfuric acid and the lignin precipitated was filtered off, washed, dried, and weighed. The content of "acid-soluble lignin" was determined by means of a UV/Vis spectrophotometer at $205 \mathrm{~nm}$ after dilution of the hydrolysate until the absorbance was in the $0.4-0.8$ range. The absorptivity value for conversion was $110 \mathrm{lg}^{-1} \mathrm{~cm}^{-1}$ (Swan 1965).

\section{Analysis of BLs}

The residual alkali concentration was determined according to the KCL procedure (number 67a:87) by titrating the diluted and carbonate-buffered BL sample to $\mathrm{pH} 11.5$ with $1 \mathrm{M} \mathrm{HCl}$.

Volatile acids (formic and acetic acids) were determined as benzyl ester derivatives (Bethge and Lindström 1974; Alén et al. 1985a) by an Agilent 6850 (Agilent Technologies, Palo Alto, CA) GC with flame ionization detection (GC/FID). A capillary column Rtx-5 (30 m×0.32 mm i.d., film thickness $0.25 \mu \mathrm{m}$; Restek, Bellefonte, PA) was used. Temperature program: $3 \mathrm{~min}$ at $60^{\circ} \mathrm{C}, \rightarrow 3^{\circ} \mathrm{C} \mathrm{m^{-1 }}$ to $150^{\circ} \mathrm{C}, \rightarrow 15^{\circ} \mathrm{C} \mathrm{min}$ to $230^{\circ} \mathrm{C}$, and $5 \mathrm{~min}$ at $230^{\circ} \mathrm{C}$. Carrier gas: $\mathrm{N}_{2}\left(0.8 \mathrm{ml} \mathrm{min}{ }^{-1}\right)$; internal standard: crotonic acid (Fluka Chemical). The temperature of both injection port and detector was $280^{\circ} \mathrm{C}$.

The hydroxy monocarboxylic and dicarboxylic acids were per(trimethylsilyl)ated with Regisil (99\% BSTFA+1\% TMCS; Regis Technologies, Morton Grove, IL) and determined as their TMS derivatives by GC/FID (Alén et al. 1984). An Rtx-5 capillary column (30 m×0.32 mm i.d., film thickness $0.25 \mu \mathrm{m}$ ) was used in GC/FID. Temperature program: $5 \mathrm{~min}$ at $60^{\circ} \mathrm{C}, \rightarrow 2^{\circ} \mathrm{C} \mathrm{min}^{-1}$ to $185^{\circ} \mathrm{C}, \rightarrow 40^{\circ} \mathrm{C}$ $\mathrm{min}^{-1}$ to $290^{\circ} \mathrm{C}$, and $5 \mathrm{~min}$ at $290^{\circ} \mathrm{C}$. Carrier gas: $\mathrm{N}_{2}\left(1.0 \mathrm{ml} \mathrm{min}^{-1}\right)$; internal standard: xylitol (Sigma-Aldrich). The temperature of injection port and detector: $290^{\circ} \mathrm{C}$ and $300^{\circ} \mathrm{C}$, respectively. The peaks were identified by mass selective detection (GC/MSD). A capillary column HP- $5 \mathrm{~ms}$ ( $30 \mathrm{~m} \times 0.25 \mathrm{~mm}$ i.d. with a film thickness of $0.25 \mu \mathrm{m}$; Agilent Technologies) was used in GC/MSD (Agilent 6890 GC equipped with Agilent 5973N MSD; Agilent Technologies). Carrier gas: He. The temperature program and the temperatures of injection port and detector were the same as those for GC/FID. The identification of the different acids was performed by comparing their mass spectra (EI at $70 \mathrm{eV}$ ) with those of the library (Wiley $7^{\text {th }}$ ed.) or with those of our laboratory. For the quantitative calculations, the mass-based response factors between xylitol and the peaks derived from the acids studied were based on data given by Alén et al. (1984).

\section{Results and discussion}

\section{Chemical composition of feedstocks}

The chemical compositions of wood materials (Table 1) are in agreement with the data of the literature. The composition of bamboo is very similar to that of HWs, although the alkali-soluble materials and ash contents (mostly silica) in bamboo are known to be high (Liese 1987; Vu 2004). According to Han and Rowell (1997), wheat straws should contain 16-21\% lignin; thus, the lignin content in wheat straw presented in Table $1(24.3 \%)$ is high. In view of the pitfalls of the 
Klason lignin determination, for example, coprecipitation of non-lignin-derived materials - polyphenols, cutins, some carbohydrate degradation products, and proteins - and problems with the determination of the acid soluble lignin, all data with this regard should be considered with care (Theander and Åman 1979). Moreover, the structure and chemical composition of nonwood materials and annual crops change considerably during their lifetime and even more rapidly after harvesting (Buchala and Wilkie 1973). As indicated by the monosaccharide data in Table 1, bamboo and wheat straw consist of cellulose and the main hemicellulose is xylan. Among others, Maekawa (1976) and Higuchi (1980) have reported that bamboo xylan has an "average structure," which is between that of HW and SW xylans.

\section{Aliphatic carboxylic acids in BLs}

The relative composition and the total amount of the main aliphatic carboxylic acids are presented in Table 4 (present in the form of sodium carboxylates) for both the wood kraft BLs at typical $\kappa$ number levels ( -30 and 20 for SW and HW, respectively) and the nonwood BLs obtained under varying conditions. The chemical structures of the main hydroxy acids in BLs are presented in Figure 1.

As found earlier by Alén et al. (1985b) and Niemelä et al. (1985), the total amount of acids formed during kraft pulping was clearly higher at an EA level of 19-21\% in the HW-BLs than in the SW-BL (Table 4). This is mainly due to the high amount of acetic acid originating from the acetyl groups of HW xylans compared with the lower acid amount obtained from SW glucomannans by deacetylation (Lindberg et al. 1973a,b). It has been shown (Niemelä et al. 1985; Zanuttini et al. 2005; Pakkanen et al. 2012) that acetyl groups are readily removed under alkaline cooking conditions.

In HW xylans, the acetyl group content varies in the range of $8-17 \%$ of the total xylan, corresponding to an average of 4-7 acetyl groups per 10 xylose units (Lindberg et al. 1973a; Alén 2011). In contrast, in SW glucomannans,

Table 4 Formation of aliphatic carboxylic acids during the pulping of various feedstocks.

\begin{tabular}{|c|c|c|c|c|c|c|c|c|c|c|}
\hline \multirow{2}{*}{$\begin{array}{l}\text { EA (\%)/Cooking temperature } \\
\left({ }^{\circ} \mathrm{C}\right)\end{array}$} & \multirow{2}{*}{$\begin{array}{r}\text { SW } \\
\text { Kraft } \\
19 / 170\end{array}$} & \multicolumn{2}{|r|}{ Birch } & \multicolumn{2}{|r|}{ Aspen } & \multicolumn{2}{|r|}{ Bamboo } & \multicolumn{3}{|c|}{ Wheat straw } \\
\hline & & $\begin{array}{r}\text { Kraft } \\
19 / 162\end{array}$ & $\begin{array}{r}\text { Kraft } \\
21 / 165\end{array}$ & $\begin{array}{r}\text { Kraft } \\
19 / 155\end{array}$ & $\begin{array}{r}\text { Kraft } \\
20 / 160\end{array}$ & Kraft/16 & Kraft/20 & Kraft/15 & $\begin{array}{l}\text { Soda- } \\
A Q / 15\end{array}$ & Soda/18 \\
\hline $\mathrm{H}$-factor & 1490 & 795 & 420 & 700 & 308 & 623 & 1080 & 18 & 18 & 380 \\
\hline$\kappa$ number & 30 & 20 & 20 & 20 & 20 & 22.5 & 12.9 & 21.3 & 22.9 & 13.7 \\
\hline Monocarboxylic acids (\%) & 88.6 & 90.6 & 90.5 & 91.8 & 88.0 & 90.3 & 88.4 & 72.8 & 75.4 & 80.6 \\
\hline Formic acid & 21.6 & 14.5 & 12.4 & 10.8 & 12.3 & 18.4 & 15.7 & 9.2 & 11.1 & 13.6 \\
\hline Acetic acid & 13.2 & 35.4 & 35.5 & 36.7 & 34.9 & 18.7 & 15.7 & 29.5 & 31.4 & 22.8 \\
\hline Glycolic acid & 4.1 & 2.6 & 2.8 & 2.4 & 2.1 & 4.3 & 4.8 & 2.1 & 4.3 & 3.3 \\
\hline Lactic acid & 10.1 & 5.6 & 5.7 & 6.1 & 5.5 & 10.0 & 10.9 & 10.3 & 6.0 & 11.0 \\
\hline Glyceric acid & - & - & - & - & - & 0.2 & 0.2 & 1.3 & 2.8 & 1.4 \\
\hline 2-Hydroxybutanoic acid & 3.0 & 11.7 & 11.1 & 10.9 & 8.8 & 15.8 & 15.0 & 4.3 & 2.5 & 8.7 \\
\hline 4-Hydroxybutanoic acid & 0.4 & 0.2 & 0.2 & 0.3 & 0.3 & 0.1 & 0.3 & 0.3 & 0.6 & 0.5 \\
\hline 2-Deoxy-tetronic acid & 0.8 & 0.7 & 0.7 & 0.6 & 0.6 & 0.2 & 0.1 & 0.2 & 0.4 & 0.2 \\
\hline 3-Deoxy-tetronic acid & 0.1 & 0.2 & 0.3 & 0.1 & 0.1 & 1.0 & 0.9 & 2.0 & 1.2 & 0.9 \\
\hline 2-Hydroxy-4-pentenoic acid & 0.7 & 0.3 & 0.3 & 0.4 & 0.3 & 0.5 & 0.6 & 0.2 & - & - \\
\hline 3,4-Dideoxy-pentonic acid & 7.5 & 2.3 & 2.4 & 2.6 & 2.4 & 4.6 & 4.6 & 4.3 & 2.4 & 2.8 \\
\hline 3-Deoxy-pentonic acid & 1.9 & 1.5 & 1.6 & 1.4 & 1.2 & 3.0 & 2.9 & 1.7 & 2.8 & 2.9 \\
\hline Xyloisosaccharinic acid & 2.0 & 8.3 & 9.8 & 9.2 & 9.3 & 6.5 & 7.5 & 2.5 & 2.4 & 4.1 \\
\hline Glucoisosaccharinic acid & 23.2 & 7.3 & 7.7 & 10.3 & 10.2 & 7.0 & 9.2 & 4.9 & 7.5 & 8.4 \\
\hline Dicarboxylic acids (\%) & 2.9 & 3.0 & 3.3 & 3.8 & 3.4 & 1.9 & 2.6 & 10.8 & 12.3 & 6.6 \\
\hline Oxalic acid & - & - & - & - & - & 0.1 & 0.2 & 2.8 & 1.9 & 0.7 \\
\hline Succinic acid & 0.5 & 0.5 & 0.5 & 0.7 & 0.4 & 0.3 & 0.8 & 0.6 & 0.8 & 1.1 \\
\hline Malic acid & 0.4 & 0.5 & 0.6 & 0.7 & 0.7 & 0.6 & 0.5 & 6.3 & 8.5 & 3.8 \\
\hline 2-Hydroxyglutaric acid & 1.3 & 1.1 & 1.2 & 1.2 & 1.0 & 0.4 & 0.8 & 0.5 & 0.6 & 0.7 \\
\hline Glucoisosaccharinaric acid & 0.7 & 0.9 & 1.0 & 1.2 & 1.3 & 0.5 & 0.3 & 0.6 & 0.5 & 0.3 \\
\hline Miscellaneous (\%) & 8.5 & 6.4 & 6.2 & 4.4 & 8.6 & 7.8 & 9.0 & 16.4 & 12.3 & 12.8 \\
\hline Total $\left(\mathrm{g} \mathrm{l}^{-1}\right)$ & 29.7 & 38.7 & 38.3 & 34.5 & 33.2 & 28.7 & 37.7 & 15.5 & 15.4 & 24.1 \\
\hline
\end{tabular}

For further cooking conditions, see Table 2. 


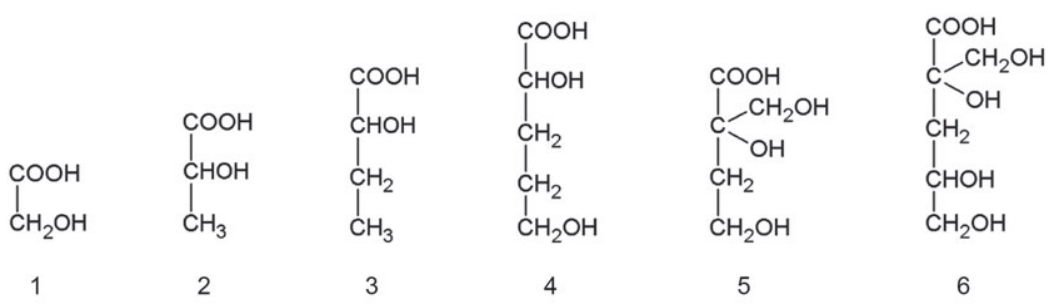

Figure 1 Main hydroxy acids in BLs: (1) glycolic acid, (2) lactic acid, (3) 2-hydroxybutanoic acid, (4) 3,4-dideoxy-pentonic acid, (5) xyloisosaccharinic acid, and (6) glucoisosaccharinic acid.

the acetyl group content is only approximately $6 \%$ of the total glucomannan, corresponding to approximately 1 acetyl group per 3-4 hexose units (Moreira and Filho 2008; Alén 2011). For this reason, HWs usually contain three to four times more acetyl groups than SWs (Fengel and Wegener 1989). In bamboo, the content of acetyl groups was found to be $6-7 \%$ of the total xylan (Higuchi 1980; Liese 1987), and in nonwood feedstock and annual plants also, glucomannans may have contain acetyl substituents (Matsuo and Mizuno 1974; Dea and Morrison 1975; Maekawa 1976). In the present study, the amount of acetic acid in bamboo BLs was closer to SW-BLs than to HW-BLs (Table 4), indicating that the bamboo (B. procera) xylan contains quite a low amount of acetyl groups.

About 15 of the most common aliphatic acids were determined. All these acid components have also been detected in earlier studies of wood BLs (Niemelä and Alén 1999). Two isomeric forms of 3-deoxy-pentonic (i.e., erythro and threo isomers) and glucoisosaccharinic (i.e., $\alpha$ and $\beta$ forms) acids could be detected (not shown separately in the tables).

The amount of formic acid in the wood kraft BLs ranged from $3.7 \mathrm{~g} \mathrm{l}^{-1}$ of the aspen BL (EA 19\%/155 ${ }^{\circ} \mathrm{C}$ ) to $6.4 \mathrm{~g} \mathrm{l}^{-1}$ of theSW-BL(Table4), whereasitsamountin the wheat kraft and soda-AQ BLs was significantly lower (1.4 and $1.7 \mathrm{~g} \mathrm{l}^{-1}$, respectively). Whereas acetic acid originates from the cleavage of acetyl groups, formic acid is gradually liberated during the peeling reaction (Sjöström 1993; Alén 2000). This explains its retarded formation at low EAs in the case of the wheat straw cook. In general, only small changes caused by the variations in EA and cooking temperature were detected in the relative composition of the aliphatic acid fraction revealed separately from SW, HWs, and bamboo. However, in the case of the wheat straw BLs, depending on the cooking method, some variations are visible. In addition, the degradation of carbohydrates to various acids with low molecular mass is markedly accelerated for wheat straw by an increase in alkali concentration and cooking temperature (see kraft/15 or soda-AQ/15 vs. soda/18).
Glucoisosaccharinic acid (Table 4) dominated the hydroxy monocarboxylic acids in the SW-BL. The next major group of these nonvolatile acids consisted of glycolic, lactic, and 3,4-dideoxy-pentonic acids. In contrast, in the case of other BLs (Table 4), the most abundant nonvolatile acids are besides glucoisosaccharinic acid, the xylan-derived 2-hydroxybutanoic and xyloisosaccharinic acids as well as minor constituents glycolic, lactic, 3,4-dideoxy-pentonic, and 3-deoxy-pentonic acids. Several dicarboxylic acids were also detected in the BLs. Although they clearly belong to the minor acid group, such a pronounced portion of these acids in wheat straw BLs was not expected. This finding can be interpreted that the prominent malic acid was derived either from pectic substances or from lignin.

\section{Alkali consumption and delignification}

The intense formation of aliphatic carboxylic acids and the rapid consumption of alkali in the beginning of both SW and birch kraft pulping can be seen in Figures $2 \mathrm{a}$ and $2 \mathrm{~b}$, respectively. Similar trends were also observed for the wheat straw cooks (Figure 3a,b). However, in the case of wheat straw, the interpretation of the results is more straightforward for two reasons: (1) the impregnation of cooking chemicals into the feedstock material is more easy and (2) the subsequent transfer of reaction products from feedstock cavities toward the external bulk liquor is less hindered (Pakkanen et al. 2013).

The characteristic progress of delignification can also be seen in Figures 2a,b and 3a,b. As expected, HW lignin degraded significantly faster than SW lignin during kraft pulping. However, more than $80 \%$ of wheat straw lignin was already removed during the heating-up period (i.e., $\mathrm{H}$-factor under 18) of kraft and soda-AQ wheat straw pulping. Wheat straw lignin is composed of guaiacyl, syringyl, and $p$-hydroxyphenylpropane moieties and this "core lignin" is further cross-linked with polysaccharides via $p$-coumaric and ferulic acids bridges (Sun et al. 1997; 


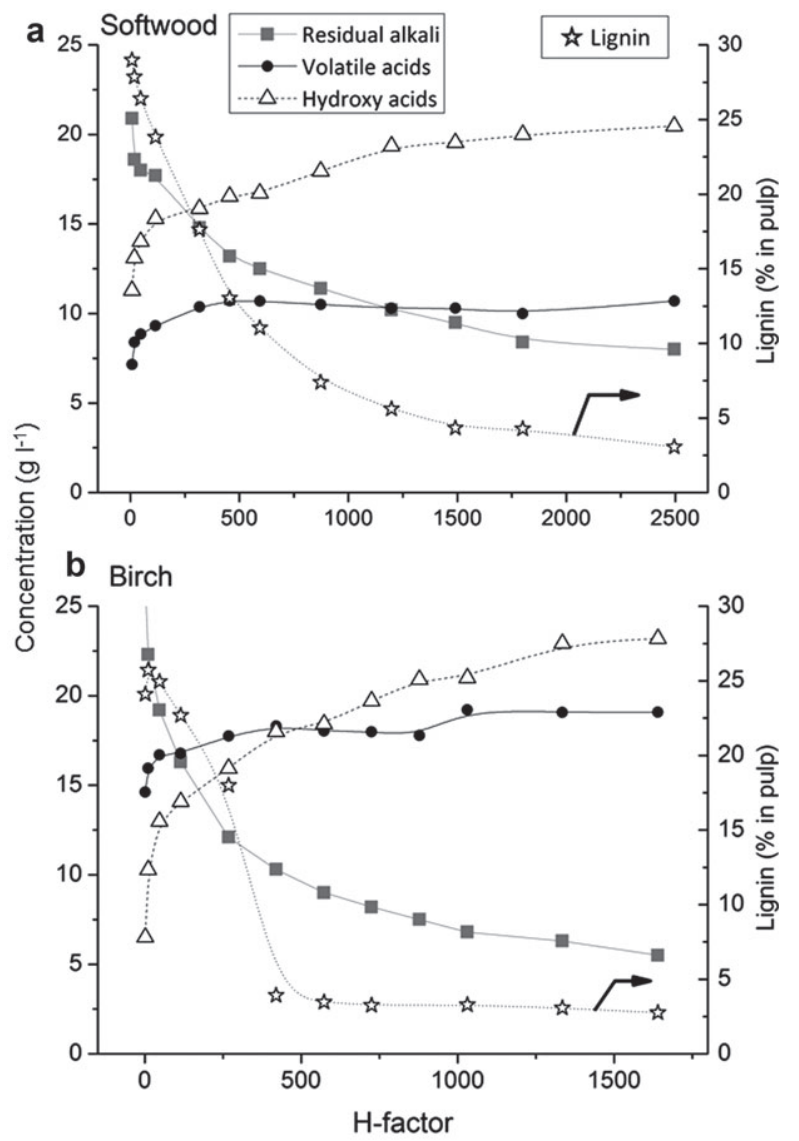

Figure 2 Formation of aliphatic carboxylic acids (volatile acids and hydroxy acids) and residual alkali as a function of $\mathrm{H}$-factor during (a) SW and (b) birch (EA $21 \% / 165^{\circ} \mathrm{C}$ ) kraft pulping.

Lignin content in wood or pulp is indicated with a mark.

Buranov and Mazza 2008). A majority of $p$-coumaric acid is bonded via alkali-labile ester bonds, which are easily released even at mild alkali extraction. These structural features together with an easy accessibility of the cell walls for chemicals are the main reasons for the rapid delignification of wheat straw.

Figures 4a,b and 5 illustrate the changes in the molar concentration of carbohydrates-derived degradation products in the course of different cooks. The consumption of alkali comprises the neutralization of aliphatic carboxylic acids, degradation products of lignin, extractives-derived compounds, and hemicellulose residues with carboxylic acid functional groups. In the presented cooks, $40-48 \%$ of the charged alkali were required in SW pulping for the formation of carboxylic acid salts (i.e., carboxylates of volatile and hydroxy acids). The corresponding values for birch and wheat straw kraft pulping were $57-71 \%$ and $42-44 \%$, respectively. The alkali consumption of the aliphatic carboxylic acids was calculated based on the carboxyl groups in each acid analyzed (i.e., for dicarboxylic acid; e.g., malic

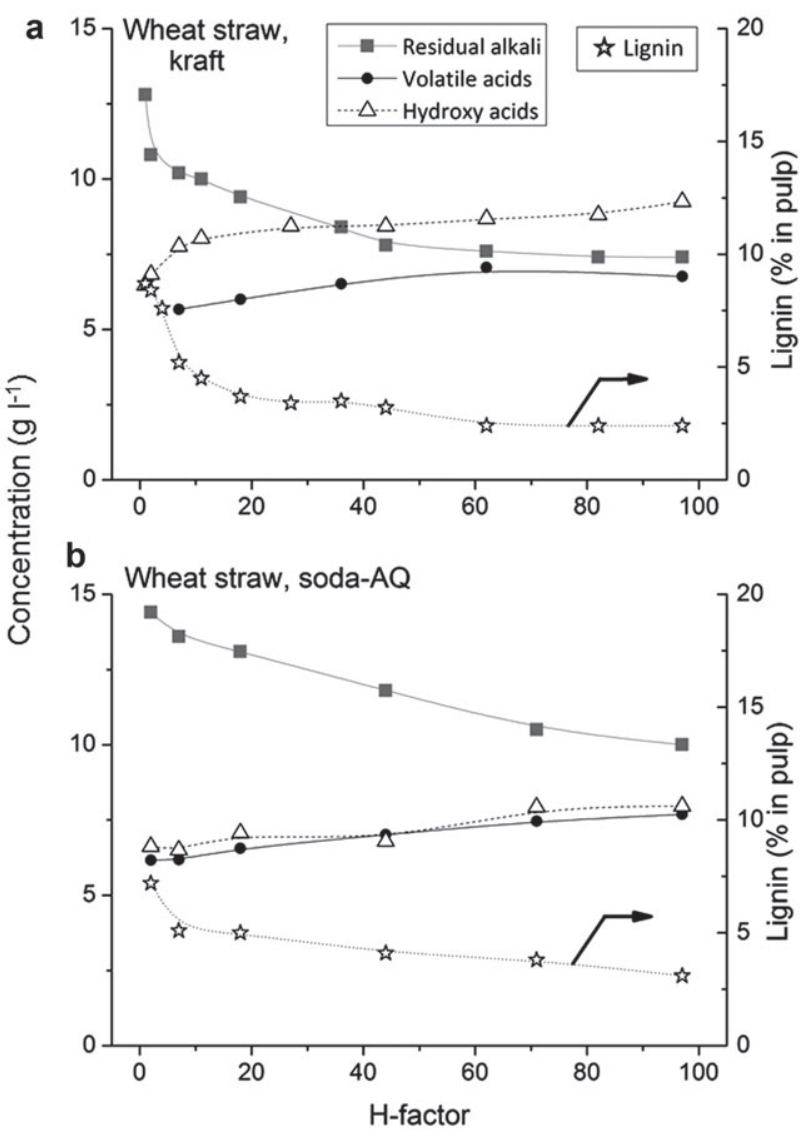

Figure 3 Formation of aliphatic carboxylic acids (volatile acids and hydroxy acids) and residual alkali as a function of $\mathrm{H}$-factor during wheat straw: (a) kraft and (b) soda-AQ pulping.

or hydroxybutenedioic acid; the alkali consumption is two equivalents of $\mathrm{NaOH}$ ).

The amount of carboxylic acids formed in kraft pulping from SW and HW is presented in Figures $6 \mathrm{a}$ and $6 \mathrm{~b}$ as kilograms of acids per ton of feedstock material. It should be pointed out that, besides volatile acids, most hydroxy acids were formed quite rapidly in the initial phase of cooking. For example, more than $50 \mathrm{~kg}$ hydroxy acids were already formed from 1 ton of the o.d. feedstock during the heatingup period before $130^{\circ} \mathrm{C}$ (SW pulping) or $145^{\circ} \mathrm{C}$ (HW pulping). On the other hand, the total amount of these acids was approximately $150 \mathrm{~kg}^{-1} \mathrm{ton}^{-1}$ of the o.d. SW and $170 \mathrm{~kg} \mathrm{ton}^{-1}$ of the o.d. birch wood at the end of the cook.

\section{Conclusions}

The H-factor-dependent profiles of the formation of aliphatic carboxylic acids (formic and acetic acids and hydroxy acids) are characteristic for SW and HWs (birch and 


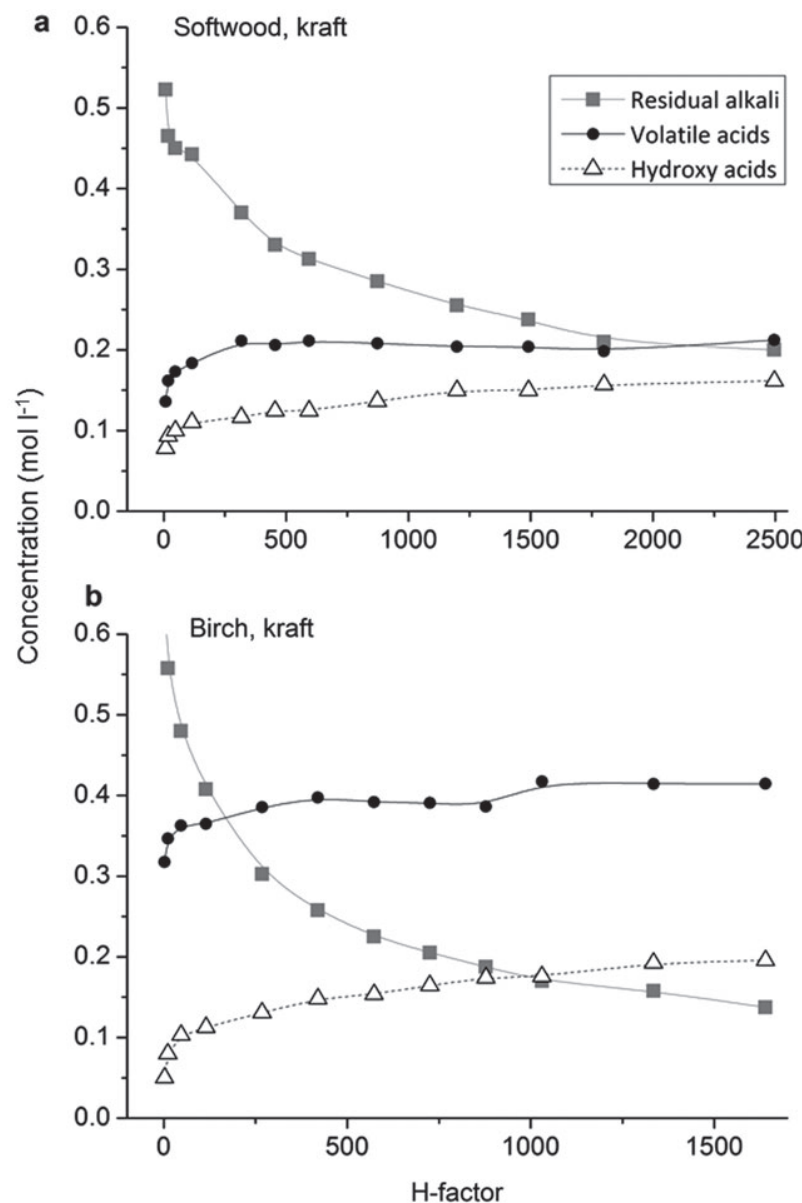

Figure 4 Molar alkali consumption of aliphatic carboxylic acids (volatile acids and hydroxy acids) and residual alkali in BLs as a function of $\mathrm{H}$-factor during (a) SW and (b) birch (EA 21\%/165 ${ }^{\circ} \mathrm{C}$ ) kraft pulping.

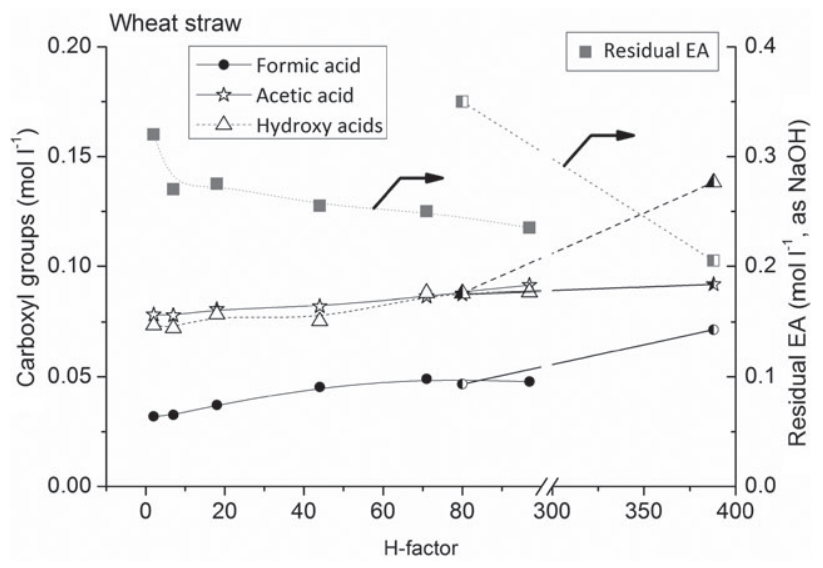

Figure 5 Molar alkali consumption of aliphatic carboxylic acids (volatile acids and hydroxy acids) and residual alkali in BLs as a function of $\mathrm{H}$-factor during wheat straw soda-AQ and soda (marked as half-filled symbols) pulping.

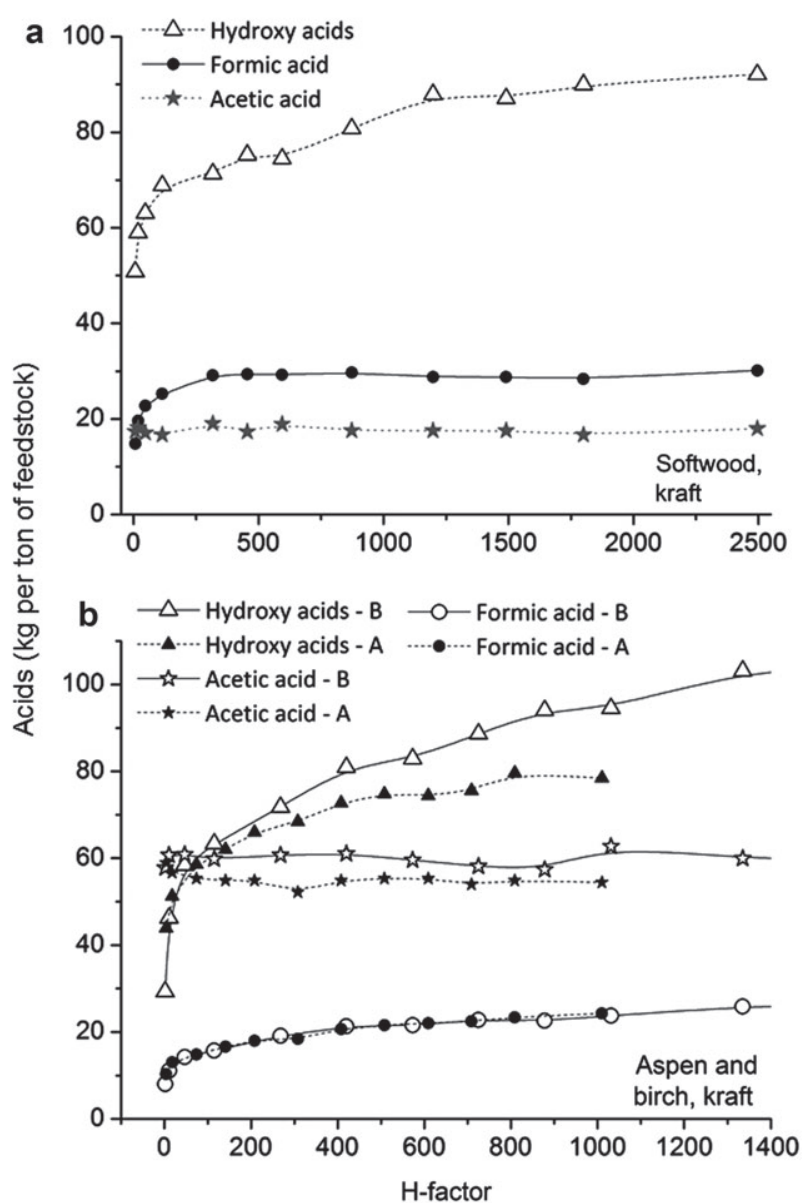

Figure 6 Amount of volatile and hydroxy acids formed during (a) SW and (b) HW kraft pulping (kilogram per ton of the o.d. feedstock). $A$, aspen; B, birch.

aspen) in conventional laboratory-scale kraft pulping. The cooks with nonwood feedstocks (bamboo and wheat straw) also revealed some peculiarities. These data are of practical importance when determining the consumption profile of the charged alkali. They are also useful, for example, in planning various recovery processes of aliphatic acids for nonfuel applications from cooking liquors formed during the initial delignification phase with low selectivity. At this stage of the cook, an acid separation process seems to be attractive in view of the high mass ratio of aliphatic acids (with low heating value) to lignin (with high heating value).

Acknowledgements: Sincere thanks are due to Mrs. Marja Salo and to our former colleague Mrs. Vu Thi Hong Mân for their skillful work in connection with the cooking experiments and analyses.

Received September 7, 2012; accepted December 19, 2012; previously published online April 11, 2013 


\section{References}

Alén, R. (2000) Basic Chemistry of wood delignification. In: Forest Products Chemistry. Eds. Stenius, P. Fapet Oy, Helsinki. pp. 58-104.

Alén, R. (2011) Structure and chemical composition of biomass feedstocks. In: Biorefining of Forest Resources. Eds. Alén, R. Paperi ja Puu Oy, Helsinki. pp. 17-54.

Alén, R., Jännäri, P., Sjöström, E. (1985a) Gas-liquid chromatographic determination of volatile fatty acids $\mathrm{C}_{1}-\mathrm{C}_{6}$, and lactic acid as their benzyl esters on a fused-silica capillary column. Finn. Chem. Lett. 12:190-192.

Alén, R., Lahtela, M., Niemelä, K., Sjöström, E. (1985b) Formation of hydroxy carboxylic acids from softwood polysaccharides during alkaline pulping. Holzforschung 39:235-238.

Alén, R., Niemelä, K., Sjöström, E. (1984) Gas-liquid chromatographic separation of hydroxy monocarboxylic acids and dicarboxylic acids on a fused-silica capillary column. J. Chromatogr. 301:273-276.

Alfredsson, B., Samuelson, O. (1968) Hydroxy acids formed by alkali treatment of hydrocellulose. Svensk Papperstidn. 71:679-686.

Bethge, O., Lindström, K. (1974) Determination of organic acids of low relative molecular mass $\left(\mathrm{C}_{1}\right.$ to $\left.\mathrm{C}_{4}\right)$ in dilute aqueous solution. Analyst 99:137-142.

Buchala, A.J., Wilkie, K.C.B. (1973) Total hemicelluloses from wheat at different stages of growth. Phytochemistry 12:499-505.

Buranov, A.U., Mazza, G. (2008) Lignin in straw of herbaceous crops. Ind. Crops Prod. 28:237-259.

Dea, I.C.M., Morrison, A. (1975) Chemistry and interactions of seed galactomannans. Adv. Carbohydr. Chem. Biochem. 31:341-312.

Fengel, D., Wegener, G. (1989) Wood-Chemistry, Ultrastructure, Reactions. Walter de Gruyter, Berlin.

Han, J.S., Rowell, J.S. (1997) Chemical composition of fibers. In: Paper and Composites From Agrobased Resources. Eds. Rowell, R.M., Young, R.A., Rowell, J. CRC Press, London. pp. 83-134.

Higuchi, T. (1980) Chemistry and biochemistry; bamboo for pulp and paper of bamboo. In: Bamboo Research in Asia. Eds. Lessard, G., Chouinard, A. Workshop Proceedings, 28-30 May, Singapore, International Development Research Centre, Ottawa. pp. 51-56.

Johansson, M.H., Samuelson, O. (1977) Reducing end groups in birch xylan and their alkaline degradation. Wood Sci. Technol. 11:251-263.

Knill, C.J., Kennedy, J.F. (2003) Degradation of cellulose under alkaline conditions. Carbohydr. Polym. 51:281-300.

Liese, W. (1987) Research on bamboo. Wood Sci. Technol. 21:189209.

Lindberg, B., Rosell, K.-G., Svensson, S. (1973a) Positions of the $O$-acetyl groups in birch xylan. Svensk Papperstidn. 76:383384.

Lindberg, B., Rosell, K.-G., Svensson, S. (1973b) Positions of the $O$-acetyl groups in pine glucomannan. Svensk Papperstidn. 76:30-32.

Löwendahl, L., Petersson, G., Samuelson, O. (1976a) Formation of carboxylic acids by degradation of carbohydrates during kraft cooking of pine. Tappi 59:118-121.
Löwendahl, L., Petersson, G., Samuelson, O. (1976b) Formation of dicarboxylic acids during hot alkali treatment of hydrocellulose. Cell. Chem. Technol. 10:471-477.

Maekawa, E. (1976) Studies on hemicellulose of bamboo. Wood Res. 59-60:153-179.

Malinen, R., Sjöström, E. (1975) The formation of carboxylic acids from wood polysaccharides during kraft pulping. Pap. Puu 57:728-736.

Matsuo, T., Mizuno, T. (1974) Acetyl groups in native glucomannan from easter lily bulbs. Agric. Biol. Chem. 38:465-466.

Moreira, L.R.S., Filho, E.X.F. (2008) An overview of mannan structure and mannan-degrading enzyme systems. Appl. Microbiol. Biotechnol. 79:165-178.

Nevell, T.P. (1985) Degradation of cellulose by acids, alkalis, and mechanical means. In: Cellulose Chemistry and its Applications. Eds. Nevell, T.P., Zeronian, Z.P. Ellis Horwood, Chichester. pp. 223-242.

Niemelä, K. (1988) GLC-MS studies on pine kraft black liquors. Part I. Identification of monomeric compounds. Holzforschung 42:169-173.

Niemelä, K. (1989) GLC-MS studies on pine kraft black liquors. Part VI. Identification of thiophenecarboxylic acids. Holzforschung 43:169-171.

Niemelä, K. (1990) Low-Molecular-Weight Organic Compounds in Birch Kraft Black Liquor. Doctoral thesis. Finnish Science Academy, Helsinki.

Niemelä, K., Alén, R. (1999) Characterization of pulping liquors. In: Analytical Methods in Wood Chemistry, Pulping, and Papermaking. Eds. Sjöström, E., Alén, R. Springer-Verlag, Heidelberg. pp. 193-231.

Niemelä, K., Alén, R., Sjöström, E. (1985) The formation of carboxylic acids during kraft and kraft-anthraquinone pulping of birch wood. Holzforschung 39:167-172.

Pakkanen, H., Paloheimo, T., Alén, R. (2013) Characterization of dissolved material during the initial phase of softwood kraft pulping. TAPPI J. 12:in press.

Rautiainen, R., Alén, R. (2010) Characterization of black liquors from kraft pulping of first-thinning Scots pine (Pinus sylvestris L.). Holzforschung 64:7-12.

Sjöström, E. (1977) The behavior of wood polysaccharides during alkaline pulping processes. Tappi 60:151-154.

Sjöström, E. (1993) Wood Chemistry-Fundamentals and Applications. Academic Press, San Diego.

Sun, R., Lawther, J.M., Banks, W.B. (1997) A tentative chemical structure of wheat straw lignin. Ind. Crops Prod. 6:1-8.

Swan, B. (1965) Isolation of acid-soluble lignin from the Klason lignin determination. Svensk Papperstidn. 68:791-795.

Theander, O., Åman, P. (1979) Studies on dietary fibers. 1. Analysis and chemical characterization of water-soluble and waterinsoluble dietary fibers. Swed. J. Agric. Res. 9:97-106.

Vu, T.H.M. (2004) Alkaline Pulping, and the Subsequent Elemental Chlorine-Free Bleaching of Bamboo. Doctoral thesis, University of Jyväskylä, Jyväskylä, Finland.

Zanuttini, M., Marzozzhi, V., Mocchiutti, P., Inalbon, M. (2005) Deacetylation consequences in pulping processes. Holz Roh-Werkst. 63:149-153. 